FINANCIAL: Jurnal Akuntansi

FINANCIAL: Jurnal Akuntansi
Published by Program Studi Akuntansi STIE Sultan Agung
Volume 7-Nomor 1, Juni 2021, (Hlm 86-96)
ISSN-P: 2502-4574, ISSN-E: 2686-2581
Available online at: https://financial.ac.id/index.php/financiaI

\title{
PENGARUH TATA KELOLA PERUSAHAAN TERHADAP KINERJA PERUSAHAAN DENGAN LEVERAGE SEBAGAI VARIABEL KONTROL
}

\author{
Giska Savira $^{1)^{*}}$, Hariyati ${ }^{2)}$ \\ ${ }^{1,2}$ Program Studi Akuntansi, Universitas Negeri Surabaya, Jl. Lidah Wetan, Lidah Wetan, Kec. \\ Lakarsantri, Kota SBY, Jawa Timur 60213, Indonesia \\ E-mail: ${ }^{1}$ giskasavira30@gmail.com, ${ }^{2}$ hariyatiunesa97@gmail.com
}

\begin{abstract}
Abstrak
Penelitian ini menguji pengaruh tata kelola perusahaan terhadap kinerja perusahaan yang diproksikan oleh Tobin's Q. Populasi penelitian adalah perusahaan manufaktur yang terdaftar di Bursa Efek Indonesia (BEI) periode 2017-2019 dengan 26 perusahaan sebagai sampel penelitian. Penelitian ini tergolong penelitian kuantitatif dengan menggunakan data dari website BEI berupa laporan keuangan dan laporan tahunan. Regresi linier berganda digunakan untuk analisis data penelitian. Indikator tata kelola perusahaan yang merupakan variabel independen adalah ukuran dewan direksi, ukuran dewan komisaris, komisaris independen, kepemilikan manajerial, dan kepemilikan institusional. Hasil studi menemukan bahwa komisaris independen, kepemilikan manajerial, dan leverage memiliki pengaruh positif terhadap kinerja perusahaan secara signifikan. Sementara itu, ukuran dewan direksi, ukuran dewan komisaris dan kepemilikan institusional tidak memiliki pengaruh secara signifikan pada kinerja perusahaan. Komisaris independen sebagai pengawas manajemen menjalankan perannya dengan baik sehingga manajemen dapat meningkatkan kinerja perusahaan melalui tinjauan dari komisaris independen. Manajer dengan tingkat kepemilikan saham yang tinggi akan meningkatkan nilai perusahaan demi memperoleh keuntungan sebagai pemegang saham. Leverage yang tinggi pada perusahaan dapat meningkatkan kinerja perusahaan dikarenakan manajemen mendapat kepercayaan dari investor untuk mengolah dana yang ditanamkannya untuk menjalankan operasional perusahaan, sehingga manajemen akan meningkatkan kinerja perusahaan sebagai bentuk pemenuhan kepentingan investor.
\end{abstract}

Kata kunci: Tata kelola perusahaan, Leverage, Tobin's $Q$

\section{THE INFLUENCE OF CORPORATE GOVERNANCE ON FIRM PERFORMANCE WITH LEVERAGE AS A CONTROL VARIABLES}

\begin{abstract}
This study examines the effect of corporate governance on firm performance as proxied by Tobin's $Q$. The research population is manufacturing companies listed on the Indonesia Stock Exchange (IDX) for the 20172019 period with 26 companies as research sample. This research is classified as a quantitative study using data from the IDX website in the form of financial reports and annual reports. Multiple linear regression is used to data analysis technique. The indicators of corporate governance which are independent variables are size of the director, size of the board of commissioners, independent commissioner, managerial ownership, and institutional ownership. The results show that independent commissioner, managerial ownership, and leverage had a significant positive effect on firm performance. Meanwhile, the size of the board of directors, the size of the board of commissioners and institutional ownership do not have a significant effect on firm performance. The independent commissioners as management supervisors carry out their roles well so that management can improve company performance through reviews from independent commissioners. Managers with a high of share ownership will increase the value of the company for the sake of obtaining benefits as shareholders. High leverage in the company can improve the firm performance because management has the trust of investors to process the funds they invest to run the firm operation, so that management will improve the firm performance as a form of fulfilling the interests of investors.
\end{abstract}

Keywords: Corporate governance, Leverage, Tobin's $Q$

Article History: Received: 19 Apr 2021 Revised: 07 Mei 2021 Accepted: 20 Mei 2021 


\section{PENDAHULUAN}

Pelemahan kinerja perusahaan sektor manufaktur di Indonesia terjadi pada tahun 2019 hingga 2020. Hal ini dapat dilihat dari data IHS Markit PMI (Purchasing's Managers Index) Manufaktur Indonesia. Data tersebut dapat mencerminkan kondisi perekonomian perusahaan secara keseluruhan, seperti hasil penjualan, persediaan, upah, serta pertumbuhan perusahaan. Data atas aspek-aspek tersebut diperoleh dari hasil survey pada tiap perusahaan yang dinyatakan dalam indeks headline PMI.

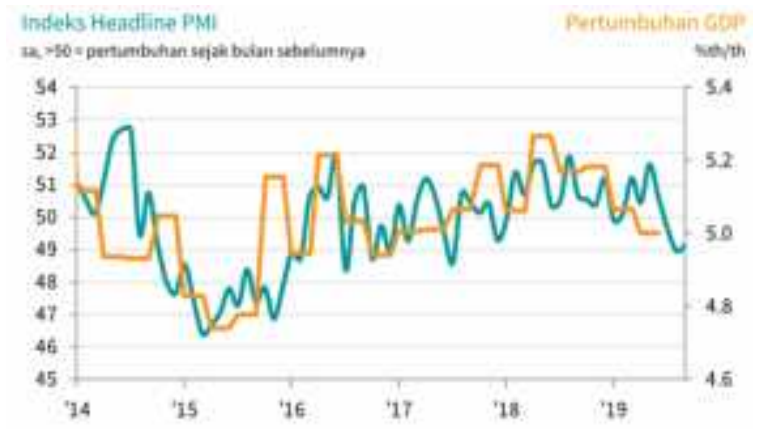

Gambar 1. Indeks Headline PMI 2019

Sumber: IHS Markit, Statistik Indonesia (BPS)

Berdasarkan gambar di atas diperoleh informasi bahwa kinerja sektor manufaktur cenderung melemah hampir terendah selama dua tahun dan cenderung mengalami penurunan hingga September 2019 dengan tingkat GDP 5\%. Penurunan kinerja sektor manufaktur disebabkan oleh penurunan permintaan dan hasil produksi, penurunan aktivitas pembelian, dan menumpuknya persediaan saat turunnya penjualan (Kepala Ekonom IHS Markit, 2019). Hingga pada Maret 2020, IHS markit menyatakan bahwa Purchasing's Managers Index (PMI) Indonesia mengalami penurunan terendah sejak 9 tahun yaitu tercatat sejak April 2011.

Adanya penurunan permintaan oleh konsumen menyebabkan hambatan dalam aktivitas pembelian sehingga berimbas pada menumpuknya persediaan yang menyebabkan perusahaan mengurangi tingkat produksi.

Dalam menyikapi kondisi tersebut, perusahaan perlu merumuskan strategi atau kebijakan perusahaan yang dapat meningkatkan kinerja perusahaan. Otoritas Jasa Keuangan (OJK) menyatakan kinerja perusahaan secara operasional dan keuangan dapat ditingkatkan dan diperbaiki melalui penerapan Good Corporate governance (GCG) (Otoritas Jasa Keuangan, 2014). GCG dapat mencerminkan kinerja perusahaan di mata para pemegang saham. (Muchtar \& Darari, 2013). Kinerja perusahaan merupakan parameter tingkat keberhasilan perusahaan dalam mengoperasikan manajemen perusahaan. Prestasi kerja perusahaan dapat digambarkan melalui penilaian kinerja perusahaan. Dengan melakukan penilaian tersebut, maka cara perusahaan dalam memperoleh keuntungan baik melalui aset, liabilitas ataupun ekuitas dapat diketahui. (Fachrudin, 2011).

Berbagai studi empiris yang menguji hubungan variabel indikator tata kelola perusahaan diantaranya, penelitian Puni \& Anlesinya (2020), menemukan pengaruh positif ukuran dewan direksi terhadap kinerja perusahaan. Sedangkan Aljifri \& Mustafa (2007) menemukan pengaruh negatif jumlah dewan direksi terhadap kinerja perusahaan. Penelitian oleh Putra (2015) dan Dewi et al. (2018) menemukan bahwa komisaris independen berpengaruh positif terhadap kinerja perusahaan. Sebaliknya, penelitian oleh Fadillah (2017) dan Ciftci et al. (2019) menemukan bahwa komisaris independen berpengaruh negatif terhadap kinerja perusahaan.

Penelitian Gunawan \& Wijaya (2020) menemukan bahwa kepemilikan manajerial 
dan kepemilikan institusional memiliki pengaruh positif dan signifikan terhadap kinerja perusahaan. Sedangkan studi empiris oleh Fadillah (2017) menemukan bahwa kepemilikan manajerial dan kepemilikan institusional berpengaruh negatif terhadap kinerja perusahaan.

Adanya research gap oleh beberapa penelitian terdahulu yang telah disebutkan di atas, menjadi motivasi penulis untuk melakukan penelitian ini. Selain itu, penulis menggunakan leverage sebagai variabel kontrol untuk mengetahui ada tidaknya pengaruh dari faktor financial pada kinerja perusahaan manufaktur. Penelitian ini menggunakan 5 (lima) indikator tata kelola perusahaan sebagai variabel independen yaitu antara lain, ukuran dewan direksi, ukuran dewan komisaris, komisaris independen, kepemilikan manajerial serta kepemilikan institusional.

\section{LANDASAN TEORI}

\section{Teori Agensi}

Teori agensi (agency theory) memahami dan mengkaji tata kelola perusahaan. Jensen \& Meckling (1976) mengungkapkan perjanjian yang dibuat oleh principal dan agen untuk membantu mengelola usaha atau organisasi dengan hak otoritas atas nama principal adalah hubungan keagenan. Dengan adanya hubungan tersebut, maka memungkinkan akan terjadi masalah keagenan. Masalah keagenan ini bermula dari adanya perbedaan tujuan atau visi antara principal dengan manajer. Principal cenderung mementingkan kekayaan serta kesejahteraan shareholders. Sedangkan manajer menginginkan kemakmuran bagi para manajer (Mariana, 2016).

\section{Stewardship Theory}

Manajemen pada prespektif stewardship berusaha untuk memenuhi kepentingan bersama dengan principal. Dalam hal ini, manajemen dapat dipercaya untuk mengelola perusahaan dikarenakan mereka tidak memiliki motif curang dan bertujuan untuk meningkatkan nilai perusahaan dengan memaksimalkan kinerjanya (Barney dalam Rashid, 2018).

\section{Tata Kelola Perusahaan}

Menurut OECD (dalam Akal, 2014), tata kelola perusahaan merupakan suatu hubungan yang melibatkan manajemen, shareholders, dan stakeholders serta bertujuan untuk mengelola dan mengendalikan perusahaan. Tata kelola perusahaan membentuk struktur untuk mencapai tujuannya dengan mengklasifikasikan tugas dengan keahlian masing-masing individu. Dengan dibentuknya struktur organisasi maka diharapkan dapat tercipta good corporate governance (GCG).

\section{Kinerja Perusahaan}

Menurut Fachrudin (2011), kinerja perusahaan dapat digambarkan sebagai kesanggupan perusahaan dalam mendapatkan keuntungan melalui asset, utang maupun ekuitas. Kinerja perusahaan dapat dicapai apabila fungsi dalam perusahaan berjalan dengan baik. Tobin's Q dalam penelitian ini dipilih sebagai alat untuk penilaian kinerja perusahaan dikarenakan mampu menggambarkan unsur utang dan ekuitas perusahaan baik melalui saham biasa, ekuitas pemegang saham hingga seluruh aset yang dimiliki perusahaan. 


\section{Hubungan Ukuran Dewan Direksi Terhadap Kinerja Perusahaan}

Dewan direksi yang berjumlah besar menunjukkan banyaknya pihak yang mengendalikan jalannya perusahaan, sehingga informasi yang beredar dalam perusahaan akan meningkat (Hadiprajitno, 2014). Jika ukuran dewan direksi kecil maka permasalahan keagenan dapat diminimalisir, pengendalian operasional perusahaan dapat terorganisir sehingga akan berimbas terhadap meningkatnya kinerja perusahaan. Ungkapan tersebut diperkuat oleh temuan Darko et al. (2016).

H1: Ukuran Dewan Direksi berpengaruh negatif terhadap kinerja perusahaan

\section{Hubungan Ukuran Dewan Komisaris Terhadap Kinerja Perusahaan}

Berdasarkan agency theory, masalah keagenan sering terjadi dikarenakan benturan visi dan misi antara principal dengan agent. Permasalahan ini dapat dicegah dengan kehadiran fungsi dewan komisaris sebagai pengawas manajemen. Apabila fungsi tersebut diterapkan dengan tepat, maka agency cost dapat diminimalisir. Penelitian Putra (2015) dan Dwi A.I (2019) membuktikan pengaruh ukuran dewan komisaris pada kinerja perusahaan adalah positif. Hal tersebut menujukkan bahwa dewan komisaris dengan skala besar menjadikan pengawasan terhadap manajemen juga semakin intens.

H2: Ukuran Dewan Komisaris berpengaruh positif terhadap kinerja perusahaan.

\section{Hubungan Komisaris Independen Terhadap Kinerja Perusahaan}

Komisaris independen memiliki kewenangan yang sama dengan dewan komisaris (Putra, 2015), namun lebih bersikap netral yakni tidak memihak suatu pihak manapun. Menurut Jensen \& Meckling (1976), besarnya pihak yang melakukan pengawasan terhadap manajer maka konflik keagenan dan biaya keagenan dapat ditekan. Chen et al., (2006) mengungkapkan bahwa besarnya komisaris independen akan mengurangi risiko aktivitas penyalahgunaan dan penipuan. Dengan demikian, ukuran komisaris independen yang besar dapat meningkatkan kinerja perusahaan. Hal yang sama juga diungkapkan oleh Shan (2019), Malik \& Makhdoom (2016), Faatihah et al. (2016), dan Dewi et al. (2018) dalam penelitiannya.

H3: Komisaris Independen berpengaruh positif terhadap kinerja perusahaan.

\section{Hubungan Kepemilikan Manajerial Terhadap Kinerja Perusahaan}

Berdasarkan studi oleh Hansen \& Crutchley (1989), masalah keagenan dapat ditekan dengan tingginya proporsi saham yang dimiliki manajer. Manajemen dengan proporsi kepemilikan yang besar akan meningkatkan nilai perusahaan, sehingga dapat memperoleh keuntungan melalui harga saham. Penelitian Farooque et al. (2019), Shan (2019), dan Gunawan \& Wijaya (2020) membuktikan pengaruh kepemilikan manajerial pada kinerja perusahaan secara positif.

H4: Kepemilikan manajerial berpengaruh positif terhadap kinerja perusahaan.

\section{Hubungan Kepemilikan Institusional Terhadap Kinerja Perusahaan}

Agency problem dapat terjadi karena lemahnya pengawasan oleh pemegang saham terhadap perusahaan. Apabila proporsi saham yang dimiliki besar, institusi dapat menerapkan fungsi pengawasan yang ketat terhadap manajemen. Sehingga dapat menekan adanya fraudulents (Nasrulloh, 
2017). Penelitian oleh Puni \& Anlesinya (2020) menemukan pengaruh kepemilikan institusional yang positif pada kinerja perusahaan.

H5: Kepemilikan Institusional berpengaruh positif terhadap kinerja perusahaan.

\section{Hubungan Leverage Terhadap Kinerja Perusahaan}

Leverage yang tinggi pada perusahaan, mengindikasikan bahwa perusahaan tersebut diberi kepercayaan oleh investor untuk mengelola perusahaan dengan dana yang dimilikinya. Adanya kepercayaan ini, menjadikan manajemen berperilaku sesuai dengan keinginan pemegang saham (Wulandari, 2006). Kinerja perusahaan dapat meningkat apabila perusahaan mampu mengelola leverage dengan baik. Penelitian sebelumnya membuktikan leverage berhubungan positif dengan kinerja perusahaan diantaranya oleh Detthamrong et al. (2017) dan Wulandari (2006).

H6: Leverage berpengaruh positif terhadap kinerja perusahaan.

\section{METODE}

Penelitian ini tergolong penelitian kuantitatif dengan data sekunder, berupa laporan keuangan dan laporan tahunan yang diakses dari website Bursa Efek Indonesia (BEI). Perusahaan manufaktur yang terdaftar di BEI tahun 2017-2019 dijadikan sebagai populasi penelitian. Berikut kriteria sampel penelitian berdasarkan metode purposive sampling: merupakan perusahaan manufaktur yang terdaftar di BEI periode 2017-2019 dan telah melakukan publikasi laporan keuangan serta laporan tahunan pada tahun yang bersangkutan serta memiliki data informasi terkait variabel penelitian. Berdasarkan kriteria tersebut ditentukan sampel penelitian yaitu sebesar 26 perusahaan dengan jumlah data observasi sebesar 73 data.

\section{Kinerja Perusahaan}

Variabel kinerja perusahaan diukur menggunakan tobin's $\mathrm{Q}$ atau $\mathrm{Q}$ ratio yang merupakan alat ukur kinerja perusahaan dari segi fundamental serta pasar. Data mengenai market value diperoleh dari Yahoo Finance. Sedangkan total debt dan assets diperoleh dari financial report perusahaan tahun 20172019 yang tersedia di website BEI. Penentuan nilai Tobin's Q menurut Klapper dan Love (2002) setelah penyesuaiar acddal ${ }^{\text {th h }}$ sebagai berikut.

$$
\text { Tobin's } Q=\frac{(M V E+D E B T)}{\text { Total Book Value of Assets }}
$$

Keterangan :

MVE : Market Value of Equity

DEBT : Nilai buku dari total utang

Total assets : Nilai buku dari total asset

\section{Tata Kelola Perusahaan}

Terdapat 5 (lima) indikator variabel independen tata kelola perusahaan dalam penelitian ini. Berikut pengukuran masingmasing variabel.

Ukuran Dewan Direksi (DD)

$=\sum$ Dewan Direksi

Ukuran Dewan Komisaris (DK)

$=\sum$ Dewan Komisaris

Komisaris Independen (KI)

$=\sum$ Komisaris Independen

Kepemilikan Manajerial (KM)

$=\frac{\text { Jlh saham manajer, direksi, komisaris }}{\text { Jlh saham yang diterbitkan }} \times 100 \%$

Kepemilkan Institusional (KIS)

$=\frac{\text { Jumlah saham institusional }}{\text { Jumlah saham yang diterbitkan }} \times 100 \%$ 


\section{Leverage}

Tingkat leverage di perusahaan dapat ditunjukkan melalui Debt to Equity Ratio (DER). DER menggambarkan kemampuan perusahaan dalam membayar utang melalui aset yang dimilikinya. Berikut persamaan untuk menghitung DER.

$$
\text { Debt to Equity }(\mathrm{DER})=\frac{\text { Total Debt }}{\text { Total Equity }}
$$

\section{Teknik Analisis Data}

Teknik analisis data dilakukan menggunakan uji analisis regresi linier berganda. Berikut merupakan model regresi penelitian.

$$
\begin{gathered}
\text { Tobin's } Q= \\
\alpha+\beta 1 \mathrm{DD}+\beta 2 \mathrm{DK}+\beta 3 \mathrm{KI}+\beta 4 \mathrm{KM}+\beta 5 \mathrm{KI} \\
+\beta 6 \mathrm{DER}+\mathrm{e}
\end{gathered}
$$

Keterangan:

Tobin's $\mathrm{Q}=$ Kinerja Perusahaan

$\alpha \quad=$ Konstanta

$\beta_{1} D D \quad=$ Koefisien Ukuran Dewan Direksi

$\beta_{2} D K=$ Koefisien Ukuran Dewan Komisaris

$\beta_{3} K I=$ Koefisien Komisaris Independen

$\beta_{4} K M=$ Koefisien Kepemilikan Manajerial

$\beta_{5}$ KIS = Koefisien Kepemilikan Institusional

$\beta_{6} D E R=$ Koefisien Debt to Equity Ratio

e $\quad=$ Error

\section{HASIL DAN PEMBAHASAN}

\section{Uji Asumsi Klasik}

\section{Uji Normalitas}

Pada penelitian ini menggunakan Kolmogrov-Smirnov Test dalam menguji normalitas data. Untuk menormalkan data, dilakukan penghapusan data outlier pada SPSS. Sehingga diperoleh nilai signifikansi sebesar 0,188. Dengan demikian data penelitian telah berdistribusi normal.

\section{Uji Multikolinieritas}

Nilai VIF dan nilai tolerance digunakan untuk mengetahui ada tidaknya gejala multikolinieritas pada data penelitian. Berdasarkan pengujian multikolinieritas yang telah dilakukan, diperoleh nilai VIF semua variabel penelitian < 10 dan nilai tolerance > 0,1 . Dengan demikian, tidak ditemukan gejala multikolinieritas pada model penelitian.

\section{Uji Autokorelasi}

Dari pengujian autokorelasi yang telah dilakukan, nilai DW yang diperoleh adalah 1,990, nilai dU adalah 1,8019. Dengan demikian nilai $\mathrm{DW}>\mathrm{dU}$, artinya data penelitian tidak mengalami gejala autokorelasi.

\section{Uji Heterokedastisitas}

Pada penelitian ini persebaran titiktitik pada scatterplot tidak menunjukkan pola yang beraturan. Dengan kondisi demikian, model penelitian tidak mengalami adanya gejala heterokedastisitas.

\section{Uji F (Simultan)}

Setelah dilakukan uji $F$ atau uji simultan pada penelitian ini menunjukkan nilai signifikansi yaitu $0,002 \leq 0,05$. Sehingga dapat ditarik kesimpulan bahwa secara simultan variabel ukuran dewan direksi, ukuran dewan komisaris, komisaris independen, kepemilikan manajerial, kepemilikan institusional, dan leverage saling memengaruhi variabel dependen.

\section{Uji t (Parsial)}

Tabel 1. Hasil Uji t

\begin{tabular}{|c|c|c|c|c|c|}
\hline Variabel & B & $\begin{array}{c}\text { Std. } \\
\text { Error }\end{array}$ & Beta & $\mathrm{t}$ & Sig. \\
\hline (Const.) & 0,430 & 0,277 & & 1,554 & 0,125 \\
\hline DD & $-0,026$ & 0,299 & $-0,113$ & $-0,887$ & 0,378 \\
\hline DK & $-0,068$ & 0,052 & $-0,190$ & $-0,134$ & 0,193 \\
\hline KI & 0,182 & 0,073 & 0,400 & 2,504 & 0,015 \\
\hline KM & 1,959 & 0,978 & 0,235 & 2,003 & 0,049 \\
\hline KIS & 0,309 & 0,263 & 0,136 & 1,177 & 0,243 \\
\hline DER & 0,141 & 0,044 & 0,366 & 3,189 & 0,002 \\
\hline
\end{tabular}

Sumber: Data diolah penulis (2021) 
Berdasarkan uji t dengan hasil di atas, diperoleh kesimpulan variabel DD memiliki nilai sig 0,378 dengan $t$ hitung $-0,887$. Dengan demikian, H1 ditolak atau variabel DD tidak berpengaruh terhadap variabel $\mathrm{Y}$ (Tobin's Q). Variabel DK memiliki nilai sig 0,193 dengan $\mathrm{t}$ hitung -1,314. Dengan demikian, H2 ditolak atau variabel DK tidak berpengaruh terhadap variabel Y. Variabel KI memiliki nilai sig 0,015 dengan t hitung 2.504. Dengan demikian, H3 diterima atau variabel KI berpengaruh positif signifikan terhadap variabel Y. Variabel KM memiliki nilai sig 0,049 dengan t hitung 2,003. Dengan demikian, $\mathrm{H} 4$ diterima atau variabel $\mathrm{KM}$ berpengaruh positif signifikan terhadap variabel Y. Variabel KIS memiliki nilai sig 0,243 dengan $\mathrm{t}$ hitung 1,177. Dengan demikian, H5 ditolak atau variabel KIS tidak berpengaruh terhadap variabel Y. Variabel DER memiliki nilai sig 3,189 dengan thitung 0,002. Dengan demikian, H6 diterima atau variabel DER berpengaruh positif signifikan terhadap variabel Y.

\section{Uji Koefisien Determinasi}

Penelitian ini menghasilkan nilai Adjusted $R$ Square yaitu 0,234, yang menunjukkan bahwa variabel ukuran independen dapat menjelaskan variabel Tobin's Q sebesar 23,4\%, sementara 76,6\% dijelaskan oleh faktor lain, misalnya leverage, profitabilitas, dan lain-lain.

\section{Pembahasan}

\section{Pengaruh Ukuran Dewan Direksi Terhadap Kinerja Perusahaan}

Hasil uji regresi tidak membuktikan adanya pengaruh ukuran dewan direksi dengan kinerja perusahaan. Temuan ini sejalan dengan hasil penelitian oleh Yadnyapawita \& Dewi (2020). Hal ini dapat disebabkan karena jumlah dewan direksi optimal bergantung pada perusahaan masingmasing (Wulandari, 2006). Dengan demikian keefektifan kinerja suatu perusahan tidak bergantung pada besar kecilnya dewan direksi. Dewan direksi yang merupakan manajemen perusahaan berusaha senantiasa meningkatkan kinerja perusahaan. Dewan direksi sebagai penentu arah kebijakan perusahaan akan berusaha untuk menjadikan perusahaan baik di mata para stakeholders. Sesuai dengan asumsi teori stewardship yang mengungkapkan bahwa manajemen dalam hal ini direksi tidak memiliki motif tersembunyi untuk melakukan penyimpangan melainkan berusaha menyelaraskan tujuan dengan pihak principal agar tercapai tujuan perusahaan, sehingga baik buruknya kinerja perusahaan tidak disebabkan oleh besaran dewan direksi.

\section{Pengaruh Ukuran Dewan Komisaris Terhadap Kinerja Perusahaan}

Hasil uji regresi membuktikan ukuran dewan komisaris tidak menyebabkan perubahan pada kinerja perusahaan. Hasil yang sama diungkapkan dalam penelitian Dewi et al. (2018). Hal ini dapat disebabkan oleh kurang efektifnya kinerja komisaris sehingga tidak menyebabkan adanya peningkatan kinerja perusahaan. Hal ini tidak sesuai teori agensi yang mengungkapkan agency problem dapat diminimalisir dengan kehadiran dewan komisaris.Dewan komisaris yang memiliki fungsi dalam melakukan pengawasan terhadap manajemen tidak memiliki otoritas secara langsung. Hal ini mengindikasikan bahwa dewan komisaris hanya sebatas melakukan pengawasan namun tidak meninjau dan mengarahkan manajemen dalam penerapan kebijakan perusahaan. Dengan demikian banyaknya dewan komisaris tidak menyebabkan perubahan pada kinerja perusahaan. 


\section{Pengaruh Komisaris Independen Terhadap Kinerja Perusahaan}

Hasil uji regresi menemukan komisaris independen memiliki pengaruh positif terhadap kinerja perusahaan secara signifikan. Temuan tersebut menguatkan hasil riset oleh Shan (2019), Malik \& Makhdoom (2016), dan Faatihah et al. (2016). Hal ini dikarenakan komisaris independen efektif dalam menjalankan fungsi dan tugasnya. Komisaris independen sebagai pengawas manajemen senantiasa meninjau kinerja manajemen sehingga manajemen dapat meningkatkan kinerjanya dan berdampak terhadap peningkatan kinerja perusahaan. Sesuai dengan agency theory, besarnya pihak pengawas manajemen dapat mengurangi konflik keagenan dan biaya keagenan dapat ditekan. Pengawasanyang baik dapat tercipta serta kecurangan dapat dicegah apabila proporsi komisaris independen yang tinggi (Fama, 1980). Ukuran komisaris independen yang besar dapat menghindarkan perusahaan dari konflik keagenan dikarenakan pengawasan yang dilakukan lebih intensif. Dalam hal ini komisaris independen dapat meningkatkan kinerja perusahaan dengan berperan membentuk karakter manajemen yang jujur dan berkompeten dalam bekerja.

\section{Pengaruh Kepemilikan Manajerial Terhadap Kinerja Perusahaan}

Pengujian data membuktikan adanya pengaruh positif kepemilikan manajerial terhadap kinerja perusahaan yang signifikan. Hasil ini memperkuat temuan oleh Farooque et al. (2019), Shan (2019) dan Gunawan \& Wijaya (2020). Proporsi kepemilikan saham mengindikasikan pengaruh dalam perusahaan. Manajemen dengan tingkat kepemilikan yang besar akan berusaha meningkatkan kinerja perusahaan untuk menambah nilai perusahaan di mata publik melalui kenaikan harga saham. Kondisi terebut dapat menguntungkan manajemen sebagai pemegang saham. Sesuai dengan teori agensi, adanya kesamaan kepentingan antara agen dan prinsipal dapat menekan biaya keagenan yang terjadi. Di samping itu, menggunakan asumsi signalling theory, memungkinkan bahwa tidak terjadi asimetri informasi, dikarenakan manajer sebagai pemegang saham mengetahui keadaan perusahaan atau informasi internal perusahaan sehingga dapat dengan mudah mengambil keputusan untuk keberlangsungan perusahaan. Dengan demikian, kinerja perusahaan dapat meningkat dari segi rasio q atau tobin's q, dikarenakan adanya kepercayaan pemegang saham terhadap manajemen.

\section{Pengaruh Kepemilikan Institusional Terhadap Kinerja Perusahaan}

Hasil uji data tidak menemukan adanya pengaruh kepemilikan institusional pada kinerja perusahaan. Hasil tersebut menguatkan pendapat dari Al-saidi \& Alshammari (2015). Menurut Prasetyanto \& Chariri (2013), kepemilikan saham institusional pada perusahaan tidak terkonsentrasi pada 1 (satu) institusi saja, melainkan terdapat beberapa institusi domestik serta asing sehingga terdapat diferensiasi kepentingan antar institusi dan kurangnya pengawasan terhadap manajemen. Kepemilikan institusional perusahaan yang menjadi sampel penelitian memiliki keragaman yaitu antara 33\% hingga 94\%, sehingga dapat disimpulkan bahwa terdapat kepemilikan saham pengendali yang kuat dibanding pemegang saham non pengendali. Sesuai dengan teori agensi, konflik ini merupakan konflik keagenan antar pemegang saham yang dapat memecah belah 
kepentingan bersama antara principal dengan agen. Konflik tersebut menyebabkan nilai saham perusahaan tidak menentu serta tidak berjalannya pengawasan terhadap manajemen. Perusahaan akan lebih condong terhadap pemegang saham pengendali, sehingga kepentingan bersama tidak tercapai dan ketidakseimbangan kinerja perusahaan dapat terjadi.

\section{Pengaruh Leverage Terhadap Kinerja Perusahaan}

Pengujian regresi membuktikan adanya pengaruh positif leverage yang signifikan terhadap kinerja perusahaan. Hasil ini menguatkan pendapat dari Detthamrong et al. (2017). Sampel penelitian menunjukkan tingkat DER yang rata-rata tinggi. Hal ini mengindikasikan bahwa mayoritas pendanaan perusahaan menggunakan struktur modal utang. Kondisi ini menunjukkan, pemegang saham memiliki tingkat kepercayaan yang tinggi terhadap manajemen sehingga menanamkan dana yang dimilikinya pada perusahaan. Sesuai dengan asumsi teori stewardship, adanya kepercayaan tersebut menjadikan manajemen bekerja sesuai dengan kepentingan investor atau pemegang saham (Wulandari, 2006). Manajemen akan berusaha meningkatkan kinerjanya misalkan dalam aspek profitabilitas, sehingga dapat menambah nilai perusahaan melalui harga saham yang dapat menguntungkan para pemegang saham. Hal ini dilakukan untuk menjaga kredibilitas perusahaan di mata para stakeholders. Dapat disimpulkan, dengan leverage yang tinggi perusahaan dapat meningkatkan kinerja perusahaan dikarenakan adanya kepercayaan dari investor yang mendorong manajemen untuk menjaga nilai perusahaan.

\section{SIMPULAN DAN SARAN}

Berdasarkan analisis data di atas diperoleh kesimpulan bahwa kepemilikan manajerial, dan leverage berpengaruh terhadap kinerja perusahaan. Sementara itu, variabel ukuran dewan direksi, ukuran dewan komisaris, dan kepemilikan institusional tidak berpengaruh terhadap kinerja perusahaan. Komisaris independen sebagai pengawas manajemen menjalankan perannya dengan baik sehingga manajemen dapat meningkatkan kinerja perusahaan melalui tinjauan dari komisaris independen. Perubahan kinerja perusahaan juga dipengaruhi oleh kepemilikan manajerial. Manajer dengan tingkat kepemilikan yang besar akan meningkatkan nilai perusahaan demi memperoleh keuntungan untuk diri sendiri sebagai pemegang saham. Selanjutnya, leverage yang tinggi pada perusahaan manufaktur dapat meningkatkan kinerja perusahaan dikarenakan manajemen mendapat kepercayaan dari investor untuk mengolah dana yang ditanamkannya untuk menjalankan operasional perusahaan, sehingga manajemen akan meningkatkan kinerja perusahaan sebagai bentuk pemenuhan kepentingan investor. Penelitian ini terbatas dalam menggunakan satu sektor perusahaan saja untuk objek penelitian. Peneliti berikutnya disarankan untuk memperluas sampel penelitian dengan menambah sektor perusahaan.

\section{DAFTAR PUSTAKA}

Akal, M. N. (2014). Corporate Governance (Konsep, Teori dan Perbandingan Pelaksanaan Beberapa Negara Asia).

Al-saidi, M., \& Al-shammari, B. (2015). Ownership Concentration , Ownership Composition and The Performance of the Kuwaiti listed non-financial firms. International Journal of Commerce and Management, 25(1), 108-132. 
Aljifri, K., \& Mustafa, M. (2007). The Impact of Corporate Governance Mechanisms on the Performance of UAE Firms: An Empirical Analysis. Journal of Economic \& Administrative Sciences, 23(2), 71-93.

Chen, G., Firth, M., Gao, D. N., \& Rui, O. M. (2006). Ownership structure, corporate governance, and fraud: Evidence from China. Journal of Corporate Finance, 12, 424-448.

Ciftci, I., Tatoglu, E., Demirbag, M., \& Zaim, S. (2019). Corporate Governance and Firrm Performance in Emerging Markets : Evidence from Turkey. International Business Review, 28, 90103.

Darko, J., Aribi, Z. A., \& Uzonwanne, G. C. (2016). Corporate governance: the impact of director and board structure , ownership structure and corporate control on the performance of listed companies on the Ghana stock exchange. Corporate Governance: The International Journal for Effective Board Performance, 16(2), 259-277.

Detthamrong, U., Chancharat, N., \& Vithessonthi, C. (2017). Corporate Governance, Capital Structure and Firm Performance: Evidence from Thailand. Research in International Business and Finance, 42(July), 689-709.

Dewi, A. S., Sari, D., \& Abaharis, H. (2018). Pengaruh Karakteristik Dewan Komisaris Terhadap Kinerja Perusahaan Manufaktur Di Bursa Efek Indonesia. Jurnal Benefita, 3(3), 445. https://doi.org/10.22216/jbe.v3i3.3530

Dwi A.I, A. (2019). Pengaruh Komisaris, Komite Audit, Struktur Kepemilikan, Size, dan Leverage Terhadap Kinerja Keuangan Perusahaan Properti, Perumahan, dan Konstruksi 2013-2017. Jurnal Ilmu Manajemen, 7.

Faatihah, S., Fuzi, S., Abdul, A., \& Julizaerma, M. K. (2016). Board Independence and Firm Performance. Procedia Economics and Finance, 37(16), 460-465.
Fachrudin, K. A. (2011). Analisis Pengaruh Struktur Modal , Ukuran Perusahaan , dan Agency Cost Terhadap Kinerja Perusahaan. Jurnal Akuntansi Dan Keuangan, 37-46.

Fadillah, A. R. (2017). Analisis Pengaruh Dewan Komisaris Independen, Kepemilikan Manajerial dan Kepemilikan Institusional Terhadap Kinerja Perusahaan yang Terdaftar di LQ45. Jurnal Akuntansi, 12.

Fama, E. F. (1980). Agency Problems and the Theory of the Firm Agency Problems and the Theory of the Firm. The Journal of Political Economy, 88(2), 288-307.

Farooque, O. Al, Buachoom, W., \& Sun, L. (2019). Board , audit committee , ownership and fi nancial performance emerging trends from Thailand. Pacific Accounting Review, 54-81.

Gunawan, J., \& Wijaya, H. (2020). Pengaruh Kepemilikan Manajerial, Kepemilikan Institusional, dan Ukuran Perusahaan Terhadap Kinerja Perusahaan Manufaktur. Jurnal Multiparadigma Akuntansi Tarumanegara, 2(1), 17181727.

Hadiprajitno, P. B. (2014). Pengaruh Mekanisme Tata Kelola Perusahaan Dan Struktur Kepemilikan Terhadap Agency Cost (Studi Empiris pada Perusahaan Manufaktur yang Terdaftar di BEI Tahun 2010-2012). Diponegoro Journal of Accounting, 3(2), 669-681.

Hansen, R. S., \& Crutchley, C. E. (1989). Agency Theory of Corporate Ownership , Managerial Corporate Dividends Leverage, and Corporate Dividends. Financial Management, 18(4), 36-46.

IHS Markit PMI Manufaktur Indonesia ${ }^{T M}$ Kondisi manufaktur Indonesia terus menurun pada bulan September. (2019). IHS

Markit. https://www.markiteconomics.com/Publ ic/Home/PressRelease/c1adc4b5d83845 008e29f0f874313de4

Jensen, C., \& Meckling, H. (1976). Theory of The Firm: Managerial Behavior, 
Agency Costs and Ownership Structure. Journal of Financial Economics, 3, 305-360.

Malik, M. S., \& Makhdoom, D. D. (2016). Does corporate governance beget firm performance in Fortune Global 500 companies? Corporate Governance: The International Journal of Business in Society, 16(4), 747-764.

Mariana. (2016). Pengaruh Mekanisme Corporate Governance Terhadap Peringkat Obligasi Yang Tercatat Di Bursa Efek Indonesia Periode Tahun 2008 - 2010. AKRUAL, 7(2), 104.

Muchtar, S., \& Darari, E. (2013). Pengaruh Corporate Governance Terhadap Kinerja Perusahaan Manufaktur yang Terdaftar di Bursa Efek Indonesia. Finance and Banking Journal, 15(2).

Nasrulloh, M. B. (2017). Pengaruh struktur modal dan corporate governance terhadap kinerja perusahaan sektor pertanian di bei 2011-2014. Jurnal Ilmu Manajemen, 5(2013), 1-8.

Otoritas Jasa Keuangan. (2014). Roadmap Tata Kelola Perusahaan Indonesia Menuju Tata Kelola Emiten dan Perusahaan yang Lebih Baik.

Prasetyanto, P., \& Chariri, A. (2013). Pengaruh Struktur Kepemilikan dan Kinerja Intellectual Capital Terhadap Nilai Perusahaan (Studi Empiris pada Perusahaan Keuangan di BEI Periode Tahun 2009 - 2011). Diponegoro Journal of Accounting, 2(2), 156-167.

Puni, A., \& Anlesinya, A. (2020). Corporate governance mechanisms and firm performance in a developing country. International Journal of Marketing Studies, 62(2), 147-169.

Putra, B. (2015). Pengaruh Dewan Komisaris, Proporsi Komisaris Independen, Terhadap Kinerja Perusahaan. Jurnal Manajemen Teori Dan Terapan, 2, 70-85.

Rashid, A. (2018). Board independence and firm performance: Evidence from. Future Business Journal, 4, 34-49.

Shan, Y. G. (2019). Managerial Ownership,

Copyright (C) 2021, FINANCIAL: Jurnal Akuntansi
Board Independence and Firm Performance. Accounting Research Journal, 32(2), 203-220.

Wulandari, N. (2006). Pengaruh Indikator Mekanisme Corporate Governance Terhadap Kinerja Perusahaan Publik di Indonesia. Fokus Ekonomi, 1(2), 120136.

Yadnyapawita, I. M. D., \& Dewi, A. A. (2020). Pengaruh Dewan Direksi, Komisaris Non Independen, dan Kepemilikan Manajerial pada Kinerja Perusahaan Manufaktur di BEI. EJurnal Akuntansi Universitas Udayana, 1985-1996. 